\title{
PEMODELAN BAHAYA BANJIR DAN ANALISIS RISIKO BANJIR STUDI KASUS : KERUSAKAN TANGGUL KANAL BANJIR BARAT JAKARTA TAHUN 2013
}

\author{
Yuyus Afrianto ${ }^{1}$, Muh Aris Marfai ${ }^{2}$, dan M. Pramono Hadi ${ }^{2}$
}

Fakultas Geografi, Universitas Gadjah Mada, Yogyakarta, Indonesia ${ }^{1,2,3}$

yuyus.afrianto@yahoo.com

Diterima : Maret 2014; Direvisi : Juni 2014; Dipubikasikan: 31 Maret 2015

\begin{abstract}
ABSTRAK Bangunan pengendali banjir seperti tanggul pada Kanal Banjir Barat di Jakarta memiliki potensi kerusakan yang dapat mengakibatkan terjadinya banjir tanggul dan berdampak pada daerah di sekitarnya. Kejadian banjir tanggul pada tahun 2013 telah menyebabkan kerugian ekonomi yang cukup besar sehingga diperlukan pemodelan bahaya banjir dan penilaian kerentanan serta analisis risiko pada daerah terdampak banjir tersebut. Penelitian ini bertujuan untuk menyusun peta risiko kerugian banjir pada daerah yang mempunyai potensi rawan kerusakan tanggul di sekitar Kanal Banjir Barat. Tahapan dalam analisis penelitian ini meliputi analisis hidrologi, analisis hidraulika, penilaian kerentanan bangunan dan analisis risiko kerugian banjir. Pemetaan genangan banjir dilakukan dengan berdasarkan pada besarnya volume limpasan yang keluar dari badan tanggul sebagai hasil simulasi runtuhnya tanggul. Penilaian kerentanan bangunan dilakukan dengan memodifikasi model PTVA yang selanjutnya digunakan dalam analisis risiko untuk mengetahui berbagai tingkatan risiko kerugian bangunan pada daerah terdampak banjir tanggul. Hasil pemodelan bahaya banjir pada kejadian banjir tahun 2013 digunakan untuk mengetahui karakteristik kerusakan tanggul pada Kanal Banjir Barat. Besarnya volume limpasan pada kerusakan tanggul yang terjadi pada tahun 2013 sebesar $744.700 \mathrm{~m}^{3}$ dengan luas area terdampak banjir sebesar 39,2 Ha, sedangkan besarnya volume limpasan pada titik potensi rawan kerusakan lainnya sebesar $160.750 \mathrm{~m}^{3}$ dengan luas area terdampak banjir sebesar 9,5 Ha. Daerah terdampak banjir tanggul pada titik rawan kerusakan lainnya tersebut mencakup sebagian wilayah Kelurahan Kota Bambu Utara dan Kelurahan Jati Pulo. Hasil akhir dari perhitungan analisis risiko spesifik bangunan secara kuantitatif menunjukkan bahwa lingkungan RW II pada Kelurahan Kota Bambu Utara merupakan daerah yang mempunyai tingkat risiko paling tinggi terhadap banjir dengan jumlah risiko spesifik bangunan mencapai Rp 737,72 Juta dari total risiko spesifik bangunan sebesar Rp 1,97 Miliar.
\end{abstract}

Kata kunci: analisis; banjir; pemetaan; pemodelan; risiko; tanggul.

ABSTRACT The structure of the canal; such as its levee in Jakarta; has a potential to fail that can cause flooding to the surrounding area. The levee breach in 2013 had caused major economy loss; thus there is a need to develop a model of the hazard and its risk analysis to the area affected. The purpose of this research is to create risk map from flood hazard to the potential affected area where the levee might fail again in the West Flood Canal. Steps taken for the research analysis are hydrological analysis; hydraulic analysis; building vulnerability assessment and risk analysis. The flood hazard map was created from the modeling of levee breachbased on volume of flow leaving from the result of simulation. Building vulnerability assessment was conducted using a modified PVTA model then used to calculate the risk analysis to find out the level of risk of the buildings in the affected areas. The outcome shows that the characteristic of the damage in the levee for the 2013 levee breach on the West Flood Canal was used for the model. The volume of the outflow in 2013 levee breach is $744.700 \mathrm{~m}^{3}$ affecting the area of 39;2 ha;on the other hand; the volume of the outflow on the predicted area is $160.750 \mathrm{~m}^{3}$ affecting an area of 9;5 Ha. Another affected area for potential levee breach consists of Kelurahan Kota Bambu Utara and Kelurahan Jati Pulo. The end result of the risk analysis shown that RW II in Kelurahan Kota Bambu Utara is the area that has the highest risk from flood with total loss from the building in RW II is up to Rp 737;72 million from the overall building loss is Rp 1;97 billion.

Key words: analysis; flood; mapping; modeling; risk; levee.

\section{PENDAHULUAN}

Jakarta sebagai ibukota Indonesia; merupakan salah satu megacity di kawasan Asia Tenggara dengan pertumbuhan jumlah penduduk yang sangat tinggi.
Tingkat pertambahan penduduk yang tinggi ini menimbulkan tekanan pada lingkungan hidup Jakarta yang semakin lama semakin berat. Perpaduan antara kondisi geografis yang rendah dan dialiri oleh banyak 
sungai; serta kian rusaknya lingkungan hidup akibat tekanan pertumbuhan penduduk; menyebabkan Jakarta kian lama kian rentan terhadap ancaman bencana banjir. Fenomena banjir Jakarta sebenarnya sudah ada sejak zaman pemerintah Kolonial Belanda. Hanya berselang dua tahun setelah Batavia dibangun lengkap dengan sistem kanalnya; tahun 1621 kota ini mengalami banjir. Berbagai macam variasi kejadian banjir telah terjadi di daerah Glodok; Pejambon; Kali Besar; Gunung Sahari dan Kampung Tambora. Salah satu upaya penanggulangan banjir yang dilakukan oleh pemerintah Kolonial setelah banjir besar tahun 1918 adalah membangun saluran air yang disebut sebagai Kanal Banjir Barat pada tahun 1922. Pembangunan kanal ini bertujuan untuk melindungi kawasan kota dari banjir tetapi tidak melindungi daerah-daerah lainnya. Kanal Banjir Barat dengan panjang 17;5 km ini; dirancang mampu mengendalikan air yang masuk ke kota Batavia; dan menampung air Sungai Ciliwung; Sungai Cideng; Sungai Krukut dan Sungai Grogol (Sakethi, 2010). Akan tetapi selama kurun waktu sekitar tiga perempat abad (1911 - 1985); berbagai macam usaha pemerintah untuk mengendalikan banjir termasuk dengan membangun berbagai kanal; terbukti tidak mampu membebaskan warga Jakarta dari ancaman banjir pada setiap musim penghujan (Gunawan, 2010).

Banjir di kota Jakarta berkaitan erat dengan banyak faktor; diantaranya pembangunan fisik di kawasan tangkapan air di hulu yang kurang tertata baik; urbanisasi yang terus meningkat; perkembangan ekonomi dan perubahan iklim global. Dengan perkembangan tata guna lahan di kawasan hulu dewasa ini; terjadi peningkatan debit yang masuk Kanal Banjir Barat (KBB) yaitu dari Kali Baru; Kali Cideng; Kali Krukut; dan Kali Angke sehingga menyebabkan kapasitas aliran KBB sudah tidak memadai lagi. Dengan bertambahnya debit aliran dari hulu akan berpengaruh terhadap bangunan pengendali banjir seperti bendungan; tanggul; jembatan; gorong-gorong dan sebagainya. Sebagai contoh; kasus banjir di Jakarta pada awal tahun 2013 terjadi karena rusaknya tanggul Kanal Banjir Barat; di Jalan Latuharhary; Menteng; Jakarta Pusat. Banjir tersebut tercatat telah menelan korban jiwa sedikitnya 23 orang tewas. Data terakhir bahkan menyebut 41 orang tewas akibat terseret arus air; tersengat aliran listrik dan karena sakit (Zaenuddin, 2013). Sedangkan Greenomics Indonesia memperkirakan kerugian banjir yang melanda hampir sebagian besar wilayah DKI Jakarta bisa mencapai angka $\mathrm{Rp} 15$ triliun. Kondisi tersebut didasarkan atas asumsi kedaruratan Jakarta akibat banjir dalam masa tanggap darurat selama 10 hari (17-27 Januari 2013); yang tentunya berdampak negatif pada sektor-sektor ekonomi dan perekonomian berbasis masyarakat (Untung, 2013).

Berdasarkan uraian di atas; terjadinya banjir akibat rusaknya tanggul kanal ini memberikan dampak yang cukup besar terhadap penggunaan lahan di sekitar KBB baik dari sektor infrastruktur bangunan (fisik) maupun ekonomi. Di daerah perkotaan yang padat khususnya di pusat kota; informasi terhadap bahaya banjir sangat diperlukan baik untuk kegiatan mitigasi struktural maupun non-struktural. Oleh karena itu; diperlukan penelitian lebih lanjut tentang pemodelan bahaya banjir akibat keruntuhan tanggul kanal dan analisis risiko banjir kaitannya dengan dampaknya terhadap penggunaan lahan di sekitar Kanal Banjir Barat. Dengan adanya informasi spasial tentang bahaya dan risiko banjir ini diharapkan dapat menjadi bahan pertimbangan untuk pengambilan keputusan dalam perencanaan spasial kota Jakarta. Adapun tujuan dari penelitian ini adalah sebagai berikut:

1. Untuk membuat pemodelan spasial bahaya banjir akibat keruntuhan tanggul yang terjadi di Jalan Latuharhary tahun 2013.

2. Untuk mengidentifikasi beberapa titik potensi kerusakan tanggul lainnya dan membuat simulasi model keruntuhan tanggul yang digunakan sebagai dasar untuk pemetaan bahaya banjir.

3. Untuk mengetahui tingkat kerentanan bangunan dan risiko terhadap kawasan terdampak banjir.

\section{METODE PENELITIAN}

Bahan-bahan dan variabel dalam penelitian ini dapat dilihat dalam Tabel 1. Variabel dalam penelitian ini dapat dilihat selengkapnya pada Tabel 2 Dengan mengetahui data hujan di stasiun-stasiun pengukur hujan yang berpengaruh pada DAS yang ditinjau; maka dapat dicari hubungan antara hujan yang jatuh dan debit aliran yang terjadi. Karakteristik DAS Ciliwung sebagai hulu Kanal Banjir Barat (KBB) sangat menentukan pengalihragaman dari data hujan menjadi debit aliran. Data aliran yang dihitung adalah hidrograf banjir di hulu KBB dan hidrograf banjir yang masuk di sepanjang saluran $\mathrm{KBB}$ yang dimodelkan (lateral inflow). 
Tabel 1. Bahan Penelitian

\begin{tabular}{|c|c|c|}
\hline Jenis Data & Rincian & Sumber \\
\hline Data hujan & Harian & $\begin{array}{l}\text { Balai Pengelolaan Sumber Daya Air } \\
\text { (BPSDA) Jawa Barat }\end{array}$ \\
\hline Geometri kanal & $\begin{array}{l}\text { Cross dan long section kanal } \\
\text { Bangunan melintang di kanal }\end{array}$ & $\begin{array}{l}\text { Balai Besar Wilayah Sungai (BBWS) } \\
\text { Ciliwung-Cisadane }\end{array}$ \\
\hline DEM & Hasil Olahan BBWS & $\begin{array}{l}\text { Balai Besar Wilayah Sungai (BBWS) } \\
\text { Ciliwung-Cisadane }\end{array}$ \\
\hline Foto udara & Tahun 2010 & Badan Informasi Geospasial (BIG) \\
\hline RBI & Skala 1:25000 & Badan Informasi Geospasial (BIG) \\
\hline Peta administrasi & Tingkat RW & Badan Informasi Geospasial (BIG) \\
\hline Koordinat titik penting & $\begin{array}{c}\text { Kerusakan tanggul dan bangunan } \\
\text { melintang kanal }\end{array}$ & Observasi lapangan \\
\hline
\end{tabular}

Tabel 2. Variabel penelitian

\begin{tabular}{|c|c|c|c|c|}
\hline Tujuan Penelitian & $\begin{array}{l}\text { Hasil yang } \\
\text { Diharapkan }\end{array}$ & $\begin{array}{c}\text { Parameter/ } \\
\text { Variabel }\end{array}$ & Metode & Cara Menganalisis \\
\hline $\begin{array}{l}\text { Untuk membuat } \\
\text { pemodelan } \quad \text { spasial } \\
\text { bahaya banjir akibat } \\
\text { keruntuhan tanggul yang } \\
\text { terjadi di Jalan } \\
\text { Latuharhary tahun } 2013\end{array}$ & $\begin{array}{l}\text {-Volume limpasan } \\
\text {-Peta bahaya } \\
\text { banjir }\end{array}$ & $\begin{array}{l}\text { - Geometri saluran } \\
\text { kanal } \\
\text { - DEM } \\
\text { - Peta RBI } \\
\text { - Informasi } \\
\text { kejadian banjir } \\
\text { tanggul }\end{array}$ & $\begin{array}{l}\text { - Aliran tak } \\
\text { permanen } \\
\text { (Unsteady flow } \\
\text { analysis) } \\
\text { - Kerusakan tanggul } \\
\text { mode rembesan } \\
\text { (piping) } \\
\text { - Cut and fill } \\
\text { - Survey lapangan }\end{array}$ & $\begin{array}{lr}\text { - Analisis data primer dan } \\
\text { sekunder } & \\
\text { - Pemetaan } & \text { genangan } \\
\text { dengan } & \text { berdasarkan } \\
\text { besaran } & \text { volume } \\
\text { limpasan } & \text { kerusakan } \\
\text { tanggul } & \end{array}$ \\
\hline $\begin{array}{l}\text { Untuk mengidentifikasi } \\
\text { beberapa titik potensi } \\
\text { kerusakan } \\
\text { lainnya dan membuat } \\
\text { simulasi } \\
\text { keruntuhan tanggul yang } \\
\text { digunakan sebagai dasar } \\
\text { untuk pemetaan bahaya } \\
\text { banjir }\end{array}$ & $\begin{array}{l}\text { - Titik potensi } \\
\text { rawan kerusakan } \\
\text { - Volume limpasan } \\
\text { - Peta bahaya } \\
\text { banjir }\end{array}$ & $\begin{array}{l}\text { - Geometri saluran } \\
\text { kanal } \\
\text { - DEM } \\
\text { - Peta RBI } \\
\text { - Struktur tanggul }\end{array}$ & $\begin{array}{l}\text { - Aliran tak } \\
\text { permanen } \\
\text { (Unsteady flow } \\
\text { analysis) } \\
\text { - Profil plot elevasi } \\
\text { tanggul } \\
\text { - Kerusakan tanggul } \\
\text { mode rembesan } \\
\text { (piping) } \\
\text { - Cut and fill } \\
\text { - Survey lapangan }\end{array}$ & $\begin{array}{lr}\text { - Analisis data primer dan } \\
\text { sekunder } & \\
\text { - Pemetaan } & \text { genangan } \\
\text { dengan } & \text { berdasarkan } \\
\text { besaran } & \text { volume } \\
\text { limpasan } & \text { kerusakan } \\
\text { tanggul } & \end{array}$ \\
\hline $\begin{array}{l}\text { Untuk mengetahui } \\
\text { tingkat } \\
\text { bangunan dan risiko } \\
\text { terhadap kawasan } \\
\text { terdampak banjir }\end{array}$ & $\begin{array}{l}\text { - Peta kerentanan } \\
\text { struktural } \\
\text { bangunan } \\
\text { - Peta kerentanan } \\
\text { bangunan kontak } \\
\text { dengan air } \\
\text { - Peta Indeks } \\
\text { kerentanan relatif } \\
\text { - Peta risiko } \\
\text { kerugian }\end{array}$ & $\begin{array}{l}\text { - Peta bentuk atap } \\
\text { bangunan } \\
\text { - Kondisi dan } \\
\text { struktur } \\
\text { bangunan } \\
\text { - Peta penggunaan } \\
\text { bangunan } \\
\text { - Peta administrasi } \\
\text { - Penilaian harga } \\
\text { bangunan }\end{array}$ & $\begin{array}{l}\text { Untuk mengetahui } \\
\text { tingkat kerentanan } \\
\text { bangunan dan } \\
\text { risiko terhadap } \\
\text { kawasan terdampak } \\
\text { banjir }\end{array}$ & $\begin{array}{l}\text { - Peta kerentanan } \\
\text { struktural bangunan } \\
\text { - Peta kerentanan } \\
\text { bangunan } \\
\text { dengan air } \\
\text { - Peta Indeks kerentanan } \\
\text { relatif } \\
\text { - Peta risiko kerugian }\end{array}$ \\
\hline
\end{tabular}


Untuk memodelkan aliran pada KBB digunakan program HEC-RAS 4.1.0. Program HEC-RAS 4.1.0 menggunakan pengaturan data dimana dengan data geometri yang sama bisa dilakukan kalkulasi data aliran yang berbeda-beda; begitu juga dengan sebaliknya. Data geometri terdiri dari layout pemodelan disertai cross section untuk saluran yang dijadikan model dan struktur hidraulik seperti pintu air dan jembatan (inline structure) serta asumsi runtuhnya tanggul kanal (lateral structure). Istiarto (2012) menjelaskan bahwa keruntuhan bendungan (weir) dan tanggul (levee) dapat disimulasikan dalam model pemicu keruntuhan yaitu luapan (overtopping) dan rembesan (piping). Pada penelitian ini dilakukan simulasi keruntuhan tanggul akibat rembesan pada dasar struktur tanggul yang kemudian berlanjut pada proses runtuhnya tanggul.

Metode penilaian kerentanan fisik bangunan menggunakan model PVTA-3 yang dikembangkan oleh (Dall'Osso, dkk., 2009). PTVA merupakan model penilaian kerentanan bangunan yang memperkenalkan pendekatan multikriteria beberapa elemen atribut yang berpengaruh pada bangunan. Kerentanan setiap bangunan dihitung berdasarkan kombinasi dari kerentanan sruktural bangunan dan kerentanan bangunan sebagai akibat dari tekanan hidrodinamika aliran air selama genangan serta adanya intrusi air. Model PTVA merupakan model dinamis dimana data atribut bangunan melalui bantuan ArcGIS dapat dimodifikasi dan diperbaharui secara spasial dan temporal.

Menurut Van Westen (2009b); secara konseptual penilaian risiko dilakukan dengan mengikuti persamaan (1) sebagai berikut:

Risk = Bahaya $x$ Kerentanan $x$ Elemen yang Berisikc

Pada komponen bahaya dalam persamaan tersebut sebenarnya mengacu pada peluang kejadian dari peristiwa alam yang membahayakan pada periode waktu spesifik seperti probabilitas tahunan. Sedangkan karakteristik elemen yang berisiko antara lain meliputi jumlah bangunan; jumlah penduduk dan nilai ekonomi. Lebih lanjut; Van Westen (2009b) menambahkan bahwa risiko sebenarnya dapat dihitung dengan data spasial untuk kuantifikasi risiko dengan fokus hanya pada fisik; populasi atau kerugian ekonomi. Akan tetapi; penilaian risiko secara kuantitatif dengan menggunakan persamaan (1) tersebut di atas memiliki keterbatasan untuk kerentanan aspek fisik; sedangkan aspek yang lain juga tidak kalah pentingnya. Oleh karena itu; untuk dapat menghitung risiko spesifik maka Van Westen (2009b) selanjutnya memodifikasi persamaan (1) menjadi persamaan (2) sebagai berikut:

$R=P_{T}^{*} P_{L}{ }^{*} V^{\star} A$

Maiti (2003) juga menyatakan bahwa dengan adanya kerugian fisik; (spesifik) risiko dapat dihitung sebagai produk dari kerentanan; biaya atau jumlah elemen terkena resiko dan probabilitas. Sama halnya tersebut di atas; Badilla (2002) mendefinisikan risiko sebagai jumlah yang diharapkan dari korban meninggal; lukaluka; kerusakan properti atau terganggunya aktivitas ekonomi akibat fenomena alam tertentu. Risiko adalah kombinasi dari kerentanan; kerugian elemen terkena resiko dan probabilitas. Badilla (2002) kemudian menghitung kerusakan atau kerugian akibat banjir dengan tanpa memasukkan unsur probabilitas temporal. Penilaian kerugian dapat dilakukan dengan menggunakan persamaan 3. Adapun bagan alir penelitian selengkapnya dapat dilihat pada Gambar 1.

Kerugian $=V x A$.

\section{HASIL DAN PEMBAHASAN}

Sebelum dilakukan sebuah simulasi kerusakan tanggul; maka diperlukan adanya penentuan storage area sebagai kawasan retensi atau tempat tujuan bagi limpasan air yang mengalir dari badan saluran kanal. Dalam HEC-RAS; storage area merupakan syarat dalam penggunaan lateral structure karena dapat dihubungkan dengan saluran kanal. Pada penelitian ini; storage area akan digunakan sebagai kawasan genangan yang menampung air hasil limpasan dari simulasi kerusakan tanggul KBB.

Terjadinya kerusakan tanggul di Jalan Latuharhary merupakan kegagalan tanggul akibat dari rembesan (piping). Ketika muka air maksimum pada penampang kanal sudah mendekati bagian atas tanggul maka cenderung akan menambah tekanan lateral pada struktur tanggul. Dari rangkaian proses tersebut; maka tanggul mengalami rembesan yang berakibat pada terjadinya erosi meruntuhkan tanggul sepanjang kurang lebih 60 meter. Dari hasil survey lapangan; didapatkan bahwa lokasi runtuhnya tanggul tepat di bawah jembatan layang Rasuna Said. Hal inilah yang menyebabkan konstruksi tanggul tidak cukup kuat mengingat dalam pekerjaan penguatan tanggul tidak memungkinkan menggunakan alat berat untuk memasang tiang pancang (sheet pile). Adapun simulasi proses runtuhnya tanggul dan hasil hitungan aliran banjir dapat dilihat pada Gambar 2. 


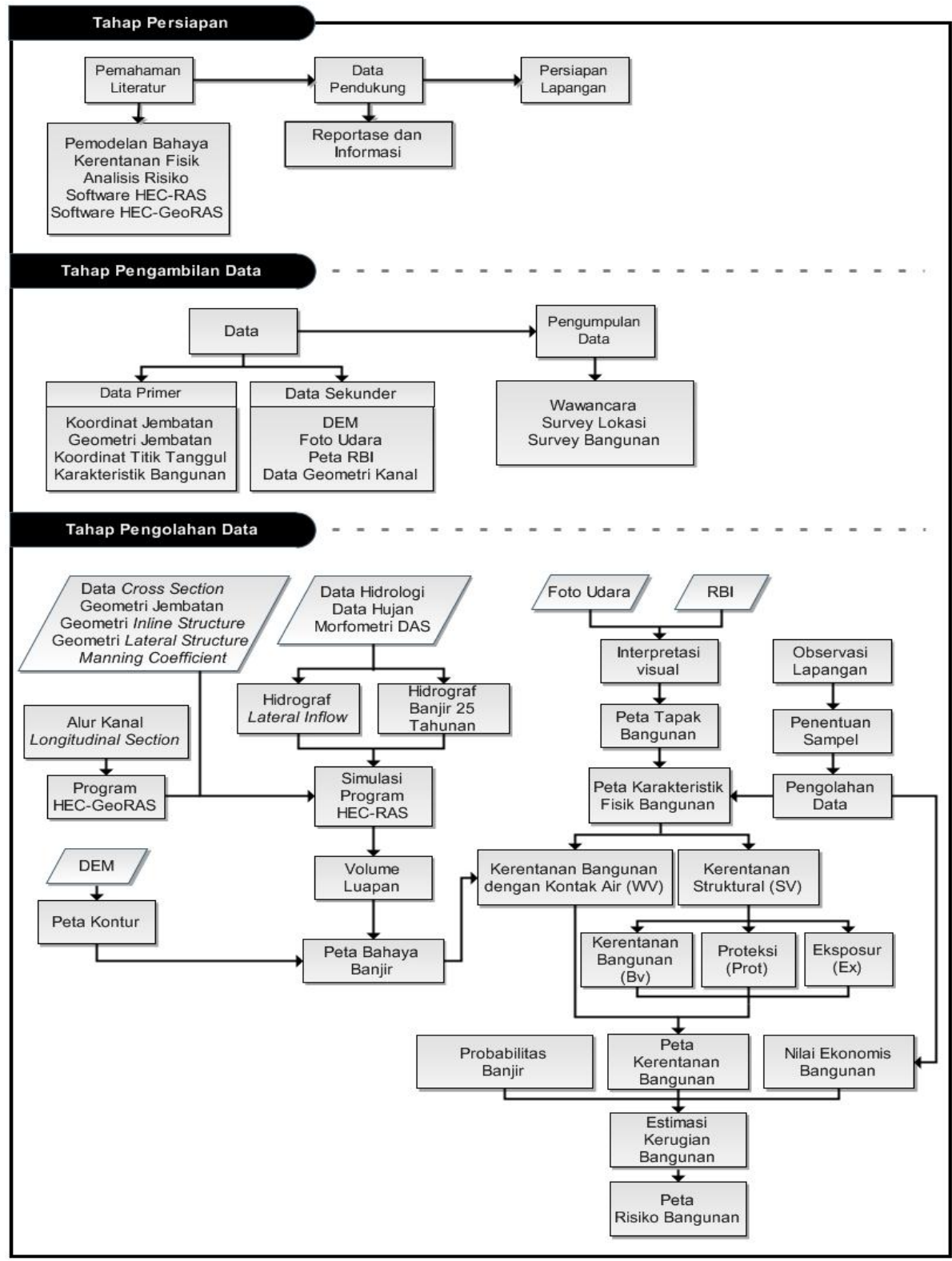

Gambar 1. Bagan Alir Penelitian

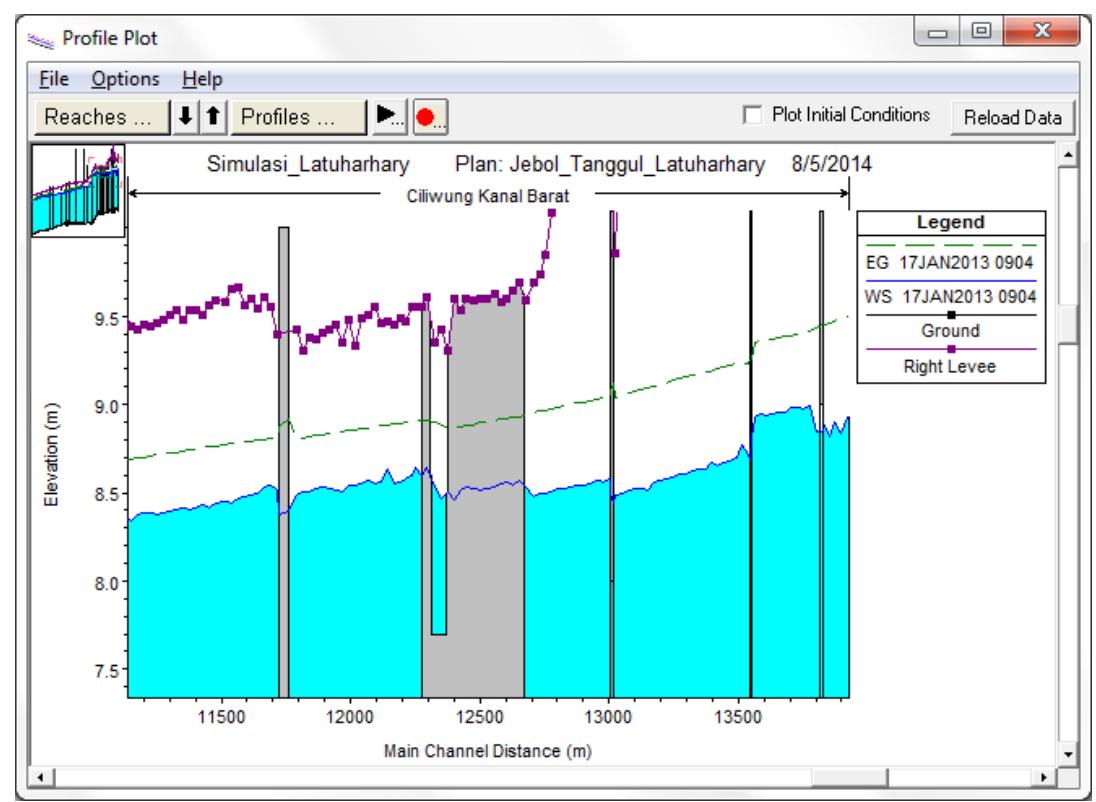

Gambar 2. Simulasi Proses Runtuhnya Tanggul di Jalan Latuharhary 
Berdasarkan hasil hidrograf banjir di atas (Gambar 3.); didapatkan perhitungan volume limpasan yang keluar melalui jalur runtuhnya tanggul sebesar 744.700 $\mathrm{m}^{3}$. Besarnya volume limpasan dipengaruhi oleh beberapa parameter penyusun data lateral structure sebagai pemodelan keruntuhan tanggul. Parameter tersebut antara lain lebar bawah dan kemiringan sisi bagian tanggul yang runtuh; koefisien debit; durasi proses keruntuhan; pilihan mode keruntuhan serta elevasi tanggul mulai runtuh dan waktu runtuh. Volume limpasan hasil perhitungan ini merupakan besarnya volume yang ditampung dalam storage area yang telah ditentukan sebelumnya dan selanjutnya akan digunakan sebagai acuan dalam analisis genangan.

Teknik yang digunakan dalam pembuatan area genangan adalah dengan bantuan software ArcGIS melalui menu cut and fill (Gambar 4). Analisa perhitungan galian dan timbunan secara sederhana dapat digunakan dengan menyamakan nilai volume timbunan sebagai besarnya volume limpasan. Volume timbunan dihitung dengan menganggap nilai elevasi minimum lahan sebagai kedalaman terendah timbunan atau dalam hal ini kedalaman minimum genangan. Sedangkan tinggi muka air genangan ditentukan berdasarkan atas asumsi elevasi yang dimasukkan sebagai batas tinggi timbunan.

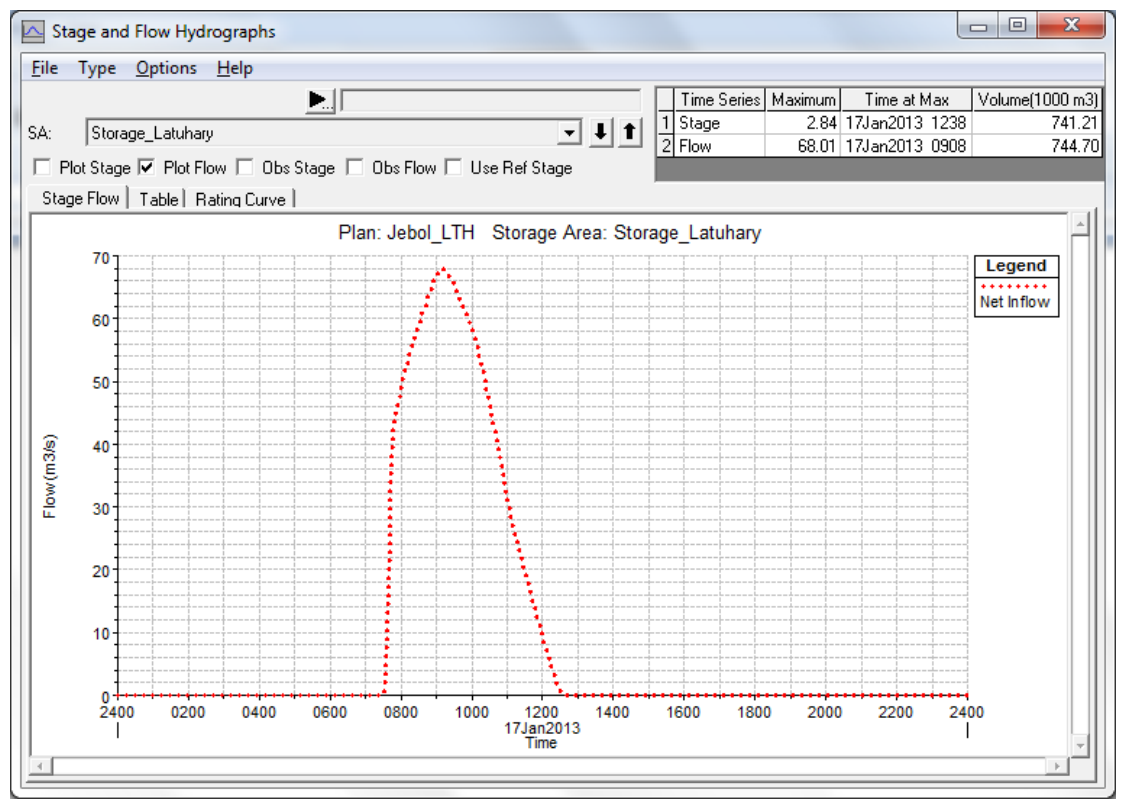

Gambar 3. Hidrograf Banjir Lateral di Jalan Latuharhary
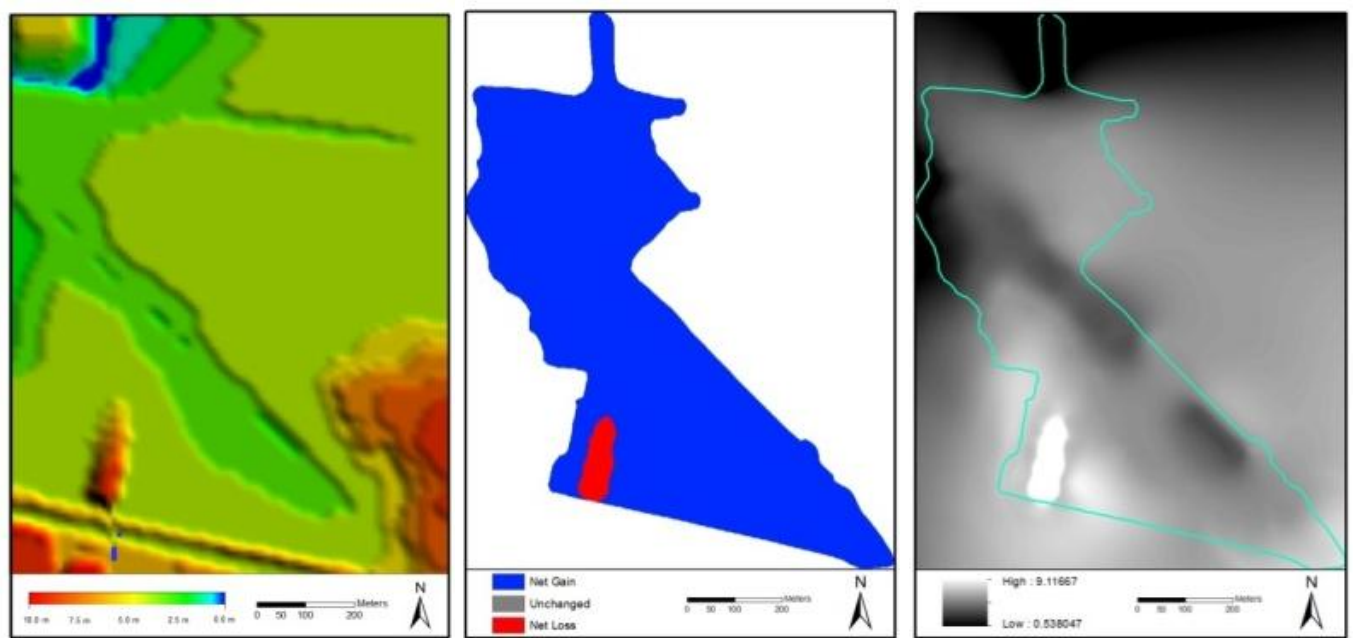

Gambar 4. Penggunaan DEM Untuk Menentukan Luasan AOI Dalam Analisis Cut and Fill 
Peta bahaya selanjutnya dapat disusun untuk mengetahui dampak banjir terhadap penggunaan lahan di sekitar tanggul. Hasil peta bahaya banjir tersebut dapat dilihat pada Gambar 5. Ada beberapa pertimbangan yang dijadikan dasar dalam menentukan titik rawan kerusakan tanggul; yaitu elevasi tanggul; struktur tanggul dan lokasi tanggul. Dalam HEC-RAS; elevasi tanggul merupakan variabel utama yang menentukan kapasitas suatu tampang lintang (cross section) untuk menampung aliran. Tinggi muka air pada suatu tampang lintang berubah-ubah sesuai dengan waktu simulasi yang ditentukan. Pada saat tinggi air maksimum; elevasi dan struktur tanggul menjadi faktor penentu terjadinya kerusakan pada tanggul itu sendiri akibat adanya tekanan lateral dari debit aliran. Salah satu cara untuk memudahkan analisis elevasi tanggul terhadap tinggi air maksimum adalah dengan menggunakan profil muka air di sepanjang alur kanal (tampang memanjang) sebagai acuannya. Dari hasil analisis profil muka air pada tanggul sebelah kiri kanal; didapatkan tiga blok titik potensi rawan dengan elevasi beberapa tanggul yang relatif rendah. Ketiga titik potensi rawan tersebut ada pada tanggul di sepanjang tampang lintang RS -57 sampai RS -61; tampang lintang RS -149 sampai RS 168 dan tampang lintang RS -195 sampai RS -207. Berikut hasil analisis titik potensi rawan berdasarkan pada profil muka air di sepanjang alur kanal (Gambar 6).

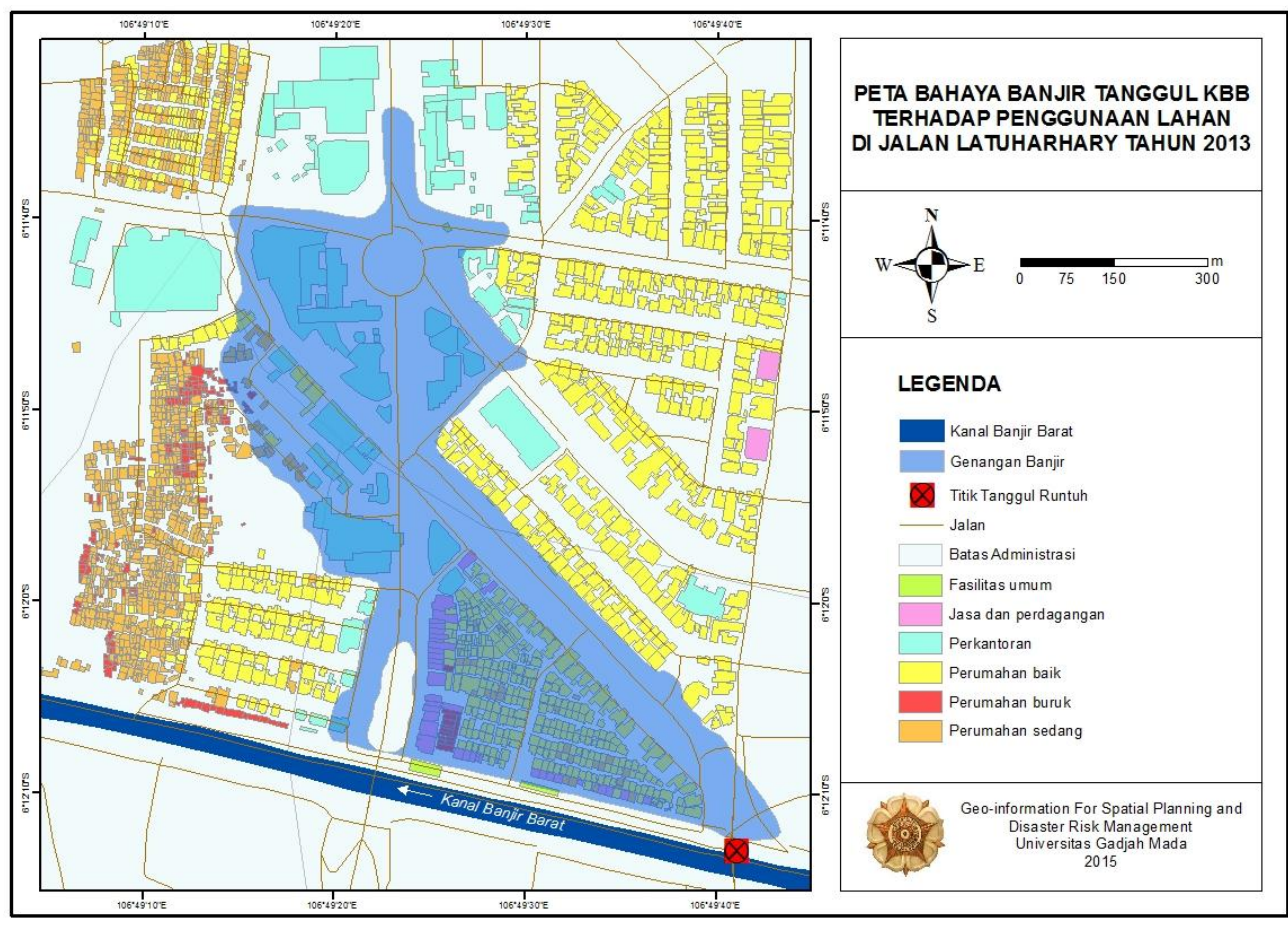

Gambar 5. Peta Bahaya Banjir Tanggul Kanal Banjir Barat terhadap Penggunaan Lahan di Jalan Latuharhary Tahun 2013

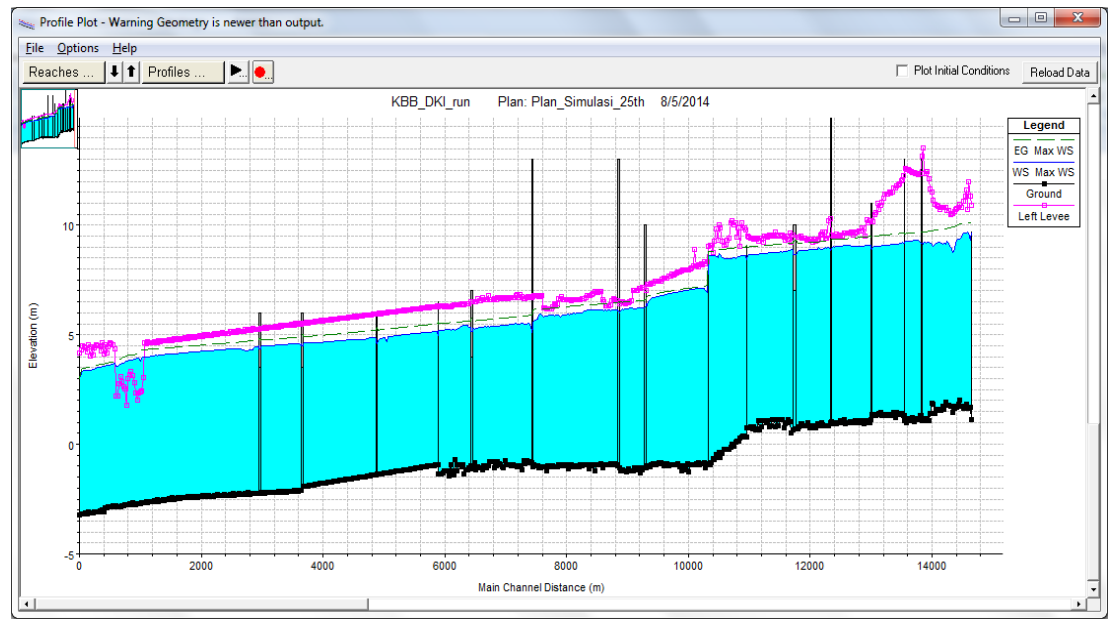

Gambar 6. Titik Potensi Rawan Tanggul (1) RS -57 sampai RS -61,

(2) RS -149 sampai RS -168, dan (3) RS -195 sampai RS -207. 
Untuk menentukan titik potensi rawan runtuh tanggul tidak cukup dianalisis melalui profil muka air di sepanjang alur kanal. Penggunaan profil muka air hanya sebatas evaluasi tanggul dan tidak mencakup kondisi struktur dan konstruksi tanggul. Oleh karena itu; diperlukan survey lapangan terhadap ketiga titik potensi rawan tersebut untuk mengetahui kondisi dan lokasi tanggul yang sebenarnya. Dari hasil survey lapangan pada titik potensi rawan (2) yaitu di sepanjang tampang lintang RS -149 sampai RS -168; didapatkan kerusakan struktur pada tanggul tepatnya pada RS -156. Kondisi struktur tanggul di titik ini ditemukan adanya retakan vertikal pada badan tanggul yang kemungkinan disebabkan karena konstruksi tanggul tidak cukup kuat menahan tekanan lateral. Kerusakan tanggul berupa retakan ini akan menyebabkan terjadinya rembesan (piping) oleh aliran air dari kanal dan apabila dibiarkan secara terus menerus dapat menjadi pemicu keruntuhan tanggul.

Pertimbangan lain yang digunakan dalam pemilihan titik potensi rawan adalah lokasi tanggul. Seperti yang sudah dijelaskan pada simulasi sebelumnya bahwa lokasi tanggul yang terletak di bawah struktur melintang seperti jembatan laying flyover) akan memiliki sistem fondasi yang tidak kuat secara konstruksi. Dengan pertimbangan tersebut maka titik potensi rawan (2) dipilih menjadi titik potensi paling rawan terjadi keruntuhan tanggul karena selain kondisi strukturnya juga lokasi tanggul terletak di bawah jembatan layang Jati Baru.Dari hasil perhitungan simulasi; didapatkan volume limpasan yang mengalir ke storage area sebesar $160.750 \mathrm{~m}^{3}$. Besarnya volume limpasan ini jauh lebih kecil jika dibandingkan dengan volume limpasan hasil simulasi sebelumnya di Jalan Latuharhary. Dalam analisis genangan; diperoleh elevasi tinggi muka air genangan sehingga luasan dan kedalaman genangan banjir pada area terdampak banjir dapat diketahui (Gambar 7). Dari hasil analisis genangan tersebut; dibuat peta bahaya banjir akibat runtuhnya tanggul di Kelurahan Kota Bambu Utara seperti pada Gambar 8.
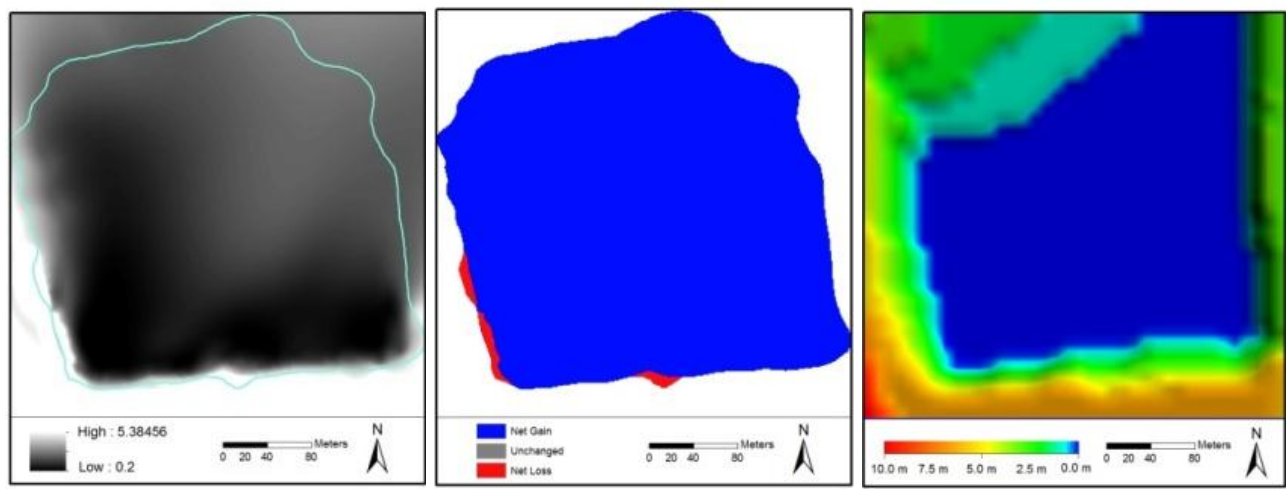

Gambar 7. Penggunaan DEM Untuk Menentukan Luasan AOI Dalam Analisis Cut and Fill

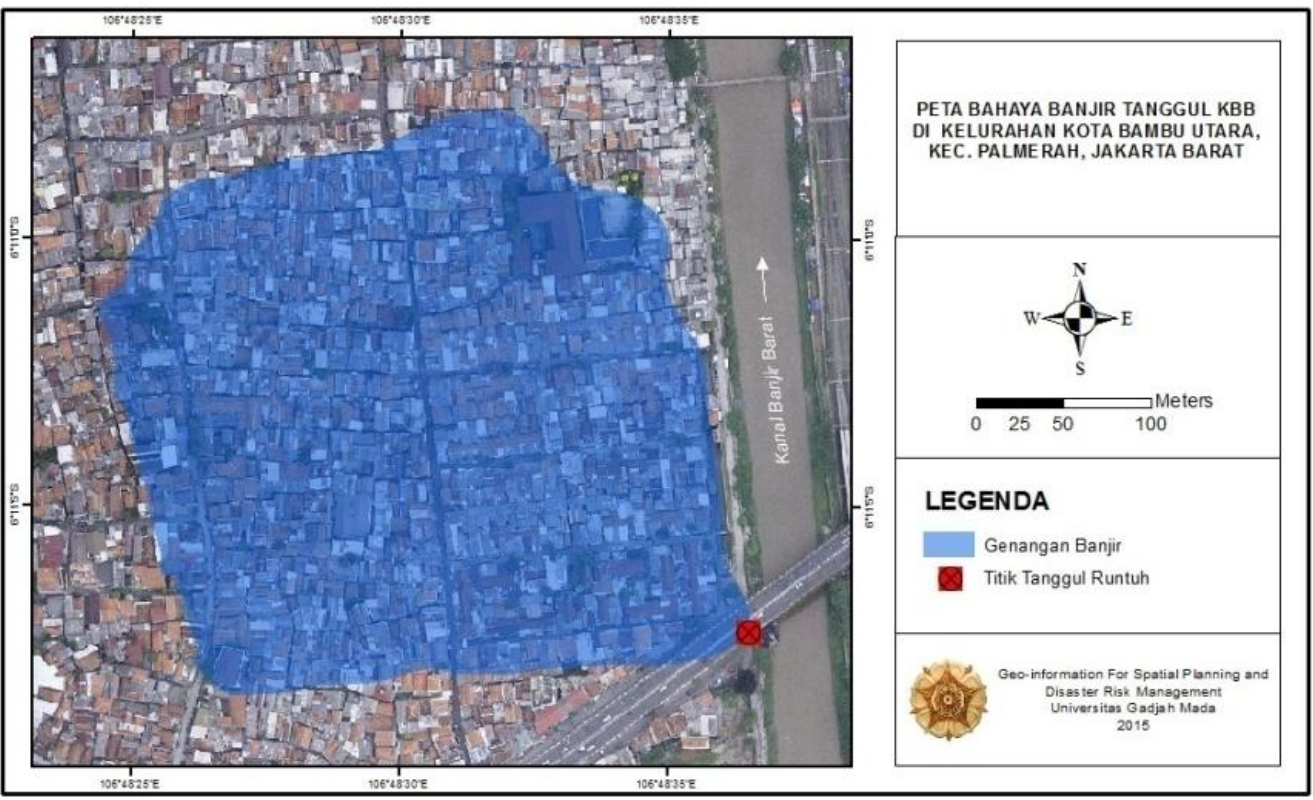

Gambar 8. Peta Bahaya Banjir Tanggul KBB di Kelurahan Kota Bambu Utara 
Dalam analisis kerentanan hanya difokuskan pada kerentanan fisik saja yaitu kerentanan bangunan. Kerentanan bangunan yang dimaksud adalah keseluruhan bangunan yang terletak pada zona bahaya sesuai dengan peta bahaya banjir tanggul KBB yang telah dibuat. Berdasarkan batas administrasi pada peta RBI; peta bahaya banjir tanggul mencakup sebagian bangunan yang ada di Kelurahan Kota Bambu Utara dan Kelurahan Jati Pulo. Lebih lanjut; batas administrasi kemudian dipersempit menjadi batas tingkat Rukun Warga (RW) untuk mendapatkan hasil yang lebih detail dalam analisis kerentanan.

Interpretasi tapak bangunan dilakukan secara visual dengan mengidentifikasi suatu bangunan melalui bentuk atapnya. Pengelompokkan bentuk atap bangunan terdiri dari 8 bentuk atap bangunan yaitu atap pelana; atap pelana modifikasi; atap limasan; atap limasan modifikasi; atap datar; atap datar modifikasi; atap masjid dan atap kompleks dan lainnya (Gambar 9). Hasil interpretasi; identifikasi dan survey lapangan menunjukkan bahwa kelompok bentuk atap pelana dan atap datar mendominasi persentase dari jumlah keseluruhan bangunan yaitu masing-masing sebesar $40 ; 1 \%$ dan 46;59 \%. Kedua kelompok bentuk atap bangunan tersebut sebagian besar penggunaan lahannya adalah pemukiman. Sedangkan persentase kelompok atap tersisa 13;31 \%; diisi oleh kelompok atap lainnya dengan penggunaan lahan yang lebih spesifik seperti pemukiman modern; kantor pemerintahan; sekolah; pasar dan masjid.

Hasil dari pengelompokkan bangunan berdasarkan bentuk atap berguna untuk memudahkan pengambilan sampel di lapangan. Oleh karena itu setiap bangunan diberikan nomor urutan berdasarkan kelompoknya pada data atribut bangunan. Dengan adanya karakteristik bentuk atap bangunan yang beragam atau heterogen maka syarat proporsional dalam sampel mutlak diperlukan untuk mewakili setiap kelompok bangunan. Kelompok yang mempunyai jumlah bangunan yang besar akan mendapatkan sampel yang lebih banyak demikian sebaliknya. Dengan tingkat signifikasi a sebesar 0;05 dan populasi bangunan sebesar 3404; maka didapatkan jumlah minimal sampel yang harus diambil sebanyak 357 bangunan. Adapun jumlah sampel dan gambaran bentuk atap bangunan untuk masing-masing kelompok dapat dilihat pada Tabel 1 dan Gambar 10.

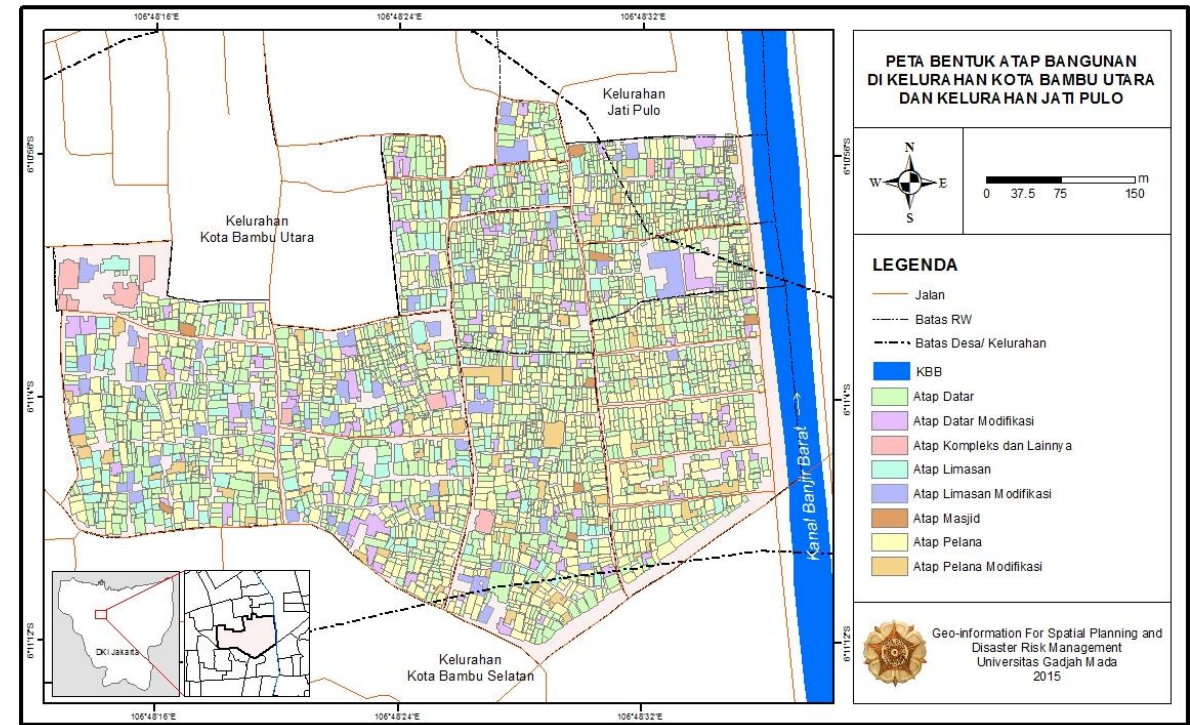

Gambar 9. Peta Bentuk Atap Bangunan di Kelurahan Kota Bambu Utara dan Kelurahan Jati Pulo

Tabel 1. Persentase dan Jumlah Sampel Pada Tiap Kelompok Bangunan

\begin{tabular}{clcccc}
\hline No & \multicolumn{1}{c}{ Bentuk Atap } & Kode & Jumlah & Persentase (\%) & Jumlah Sampel \\
\hline 1. & Atap Pelana & AP & 1365 & 40,1 & 143 \\
2. & Atap Limasan & AL & 165 & 4,85 & 17 \\
3. & Atap Datar & AD & 1586 & 46,59 & 166 \\
4. & Atap Pelana Modifikasi & APM & 89 & 2,61 & 9 \\
5. & Atap Limasan Modifikasi & ALM & 52 & 1,53 & 5 \\
6. & Atap Datar Modifikasi & ADM & 129 & 3,79 & 13 \\
7. & Atap Masjid & AM & 8 & 0,24 & 2 \\
8. & Atap Kompleks dan Lainnya & AKL & 10 & 0,29 & 2 \\
\multicolumn{2}{r}{ Jumlah Total } & & 3404 & 100 & 357 \\
\hline
\end{tabular}




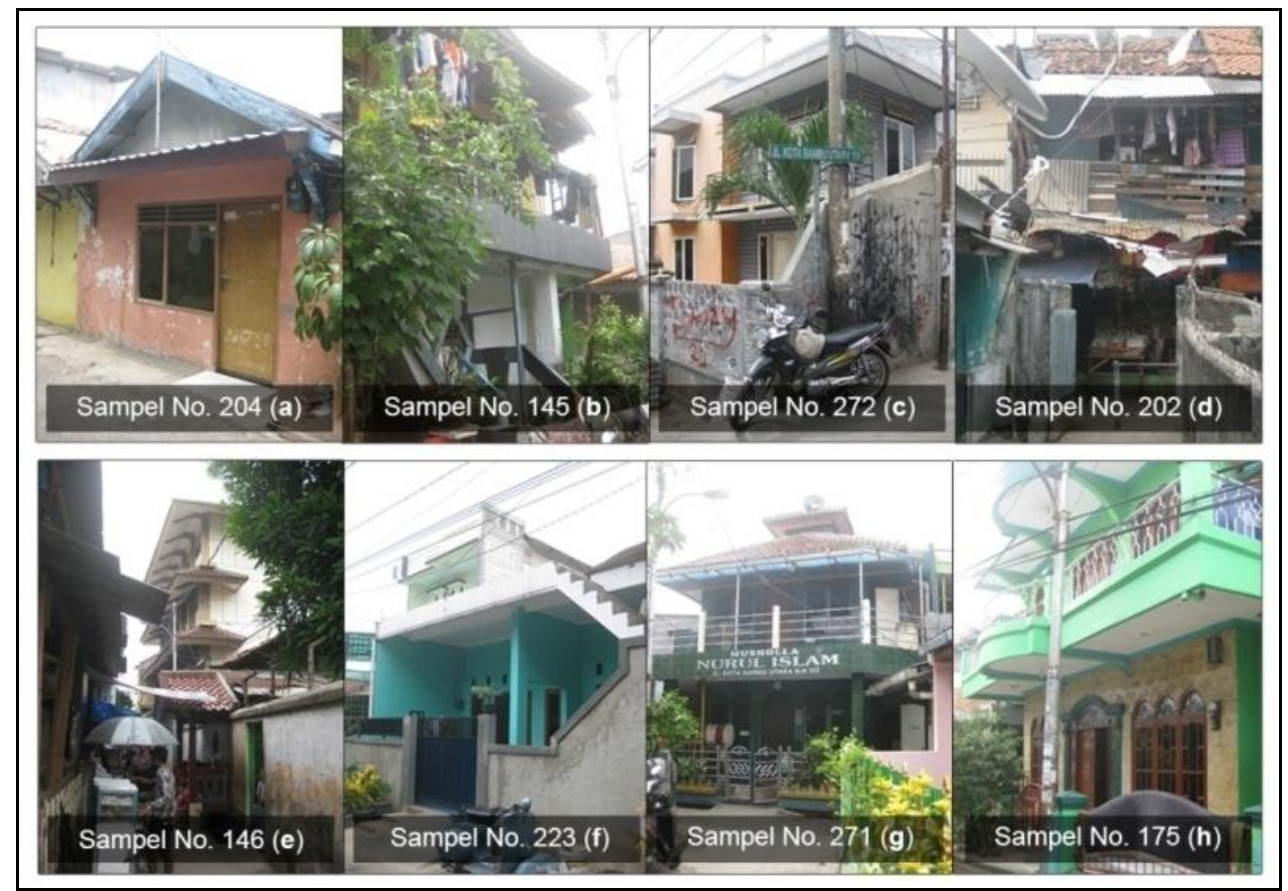

Gambar 10. Sampel Bentuk Atap Bangunan; (a) Atap Pelana, (b) Atap Limasan, (c) Atap Datar,

(d) Atap Pelana Modifikasi, (e) Atap Limasan Modifikasi, (f) Atap Datar Modifikasi,

(g) Atap Masjid dan (h) Atap Kompleks dan Lainnya

Perhitungan kerentanan struktural bangunan dilakukan dengan cara mengalikan ketiga komponen kerentanan yaitu kerentanan bangunan $(\mathrm{Bv})$; proteksi (Prot) dan eksposur (Ex). Hasil dari perhitungan menunjukkan bahwa hanya ada dua tingkat kerentanan struktural bangunan; yaitu sangat rendah dan rendah. Hal ini disebabkan karena besarnya nilai komponen eksposur relatif kecil sehingga menyebabkan berkurangnya nilai kerentanan struktural bangunan. Nilai eksposur sangat dipengaruhi oleh besar kecilnya kedalaman genangan hasil model bahaya banjir. Semakin besar kedalaman genangan banjir maka akan semakin besar nilai eksposurnya. Dalam penentuan tingkat eksposur pada model PTVA mengacu pada tingkat kejadian tsunami yang mempunyai gelombang dan genangan yang relatif lebih besar dari pada banjir. Hal inilah yang menyebabkan tidak diperoleh tingkat kerentanan struktural bangunan yang paling tinggi. Berdasarkan Tabel 2; menunjukkan bahwa lingkungan RW II pada tingkat kerentanan struktural rendah mempunyai persentase jumlah bangunan terbesar yaitu 90;03\%. Sedangkan untuk lingkungan RW IV pada tingkat kerentanan struktural sangat rendah mempunyai persentase jumlah bangunan terbesar yaitu 95;25 \%. Hasil perhitungan jumlah bangunan pada tingkat kerentanan struktural bangunan selengkapnya dapat dilihat pada Gambar 11.

Perhitungan kerentanan bangunan karena adanya kontak dengan air didasarkan pada jumlah lantai yang tergenang dan jumlah total lantai yang ada dalam suatu bangunan. Hasil perhitungan menunjukkan bahwa lingkungan RW II pada tingkat kerentanan kontak bangunan dengan air sangat tinggi mempunyai jumlah bangunan sebanyak 429 bangunan dengan persentase jumlah bangunan terbesar yaitu $75 \%$. Hampir seluruh daerah di lingkungan RW II tergenangi oleh genangan banjir hasil model bahaya banjir akibat runtuhnya tanggul. Dari keseluruhan jumlah bangunan hanya 48 bangunan yang teridentifikasi dalam kategori sangat rendah. Hal tersebut dikarenakan bangunan berada pada lahan dengan topografi yang relatif lebih tinggi sehingga terbebas dari area genangan banjir. Selain itu bangunan di lingkungan RW II tidak ada yang masuk dalam kategori rendah dikarenakan jumlah maksimal lantai bangunan hanya 2 lantai. Sementara itu; lingkungan RW IV pada tingkat kerentanan sangat rendah mempunyai jumlah bangunan sebanyak 1012 bangunan dengan persentase jumlah bangunan terbesar yaitu 94;32 \%. Hal ini disebabkan sebagian daerah pada lingkungan tersebut sangat aman dari area genangan banjir sehingga bangunan berlantai 1 pun tidak ada kontak dengan air. Hasil perhitungan jumlah bangunan pada tingkat kerentanan kontak bangunan dengan air tersaji dalam Tabel 3 dan Gambar 12.

Berdasarkan perhitungan RVI diperoleh 3 tingkat indeks kerentanan relatif; yaitu sangat rendah; rendah dan sedang. Jumlah total bangunan pada tingkat kerentanan sangat rendah sebesar 1914 bangunan atau dengan persentase sebesar 56;23 \%; sedangkan tingkat kerentanan sedang berjumlah 1230 bangunan dengan persentase sebesar $36 ; 13 \%$. Apabila dilihat dari hasil http://jurnal.ugm.ac.id/mgi | 104 
nilai RVI pada tingkat lingkungan RW; menunjukkan hasil yang hampir sama seperti pada nilai SV dan WV sebelumnya. Lingkungan RW II mendapatkan persentase jumlah bangunan terbesar pada tingkat kerentanan rendah dan sedang yaitu masing-masing 15;03 \% dan $75 \%$. Sedangkan lingkungan RW IV mendapatkan persentase jumlah bangunan terbesar pada tingkat kerentanan sangat rendah yaitu 95;25\%. Adapun hasil perhitungan jumlah bangunan pada tingkat indeks kerentanan relatif dapat dilihat pada Tabel 4 dan Gambar 13.

Penggunaan bangunan yang ada dibagi menjadi 9 jenis penggunaan bangunan antara lain pemukiman seperti rumah kondisi sangat baik; baik; sedang; buruk dan sangat buruk; kantor pemerintahan; jasa dan perdagangan; sekolah dan rumah ibadah. Hasil rekapitulasi harga bangunan berdasarkan jenis penggunaan bangunan selengkapnya dapat dilihat pada Tabel 5 .

Tabel 2. Jumlah Bangunan Pada Tingkat Kerentanan Struktural Bangunan (SV)

\begin{tabular}{clccccc}
\hline \multirow{2}{*}{ No. } & \multirow{2}{*}{ Kelurahan/ Lingkungan (RW) } & \multicolumn{5}{c}{ Kerentanan Struktural Bangunan (SV) } \\
& & Sangat Rendah & Rendah & Sedang & Tinggi & Sangat Tinggi \\
\hline 1. & Kota Bambu Utara (I) & 143 & 425 & 0 & 0 & 0 \\
2. & Kota Bambu Utara (II) & 57 & 515 & 0 & 0 & 0 \\
3. & Kota Bambu Utara (III) & 185 & 412 & 0 & 0 & 0 \\
4. & Kota Bambu Utara (IV) & 1022 & 51 & 0 & 0 & 0 \\
5. & Kota Bambu Utara (IX) & 199 & 19 & 0 & 0 & 0 \\
6. & Jati Pulo (X) & 310 & 66 & 0 & 0 & 0 \\
\hline
\end{tabular}

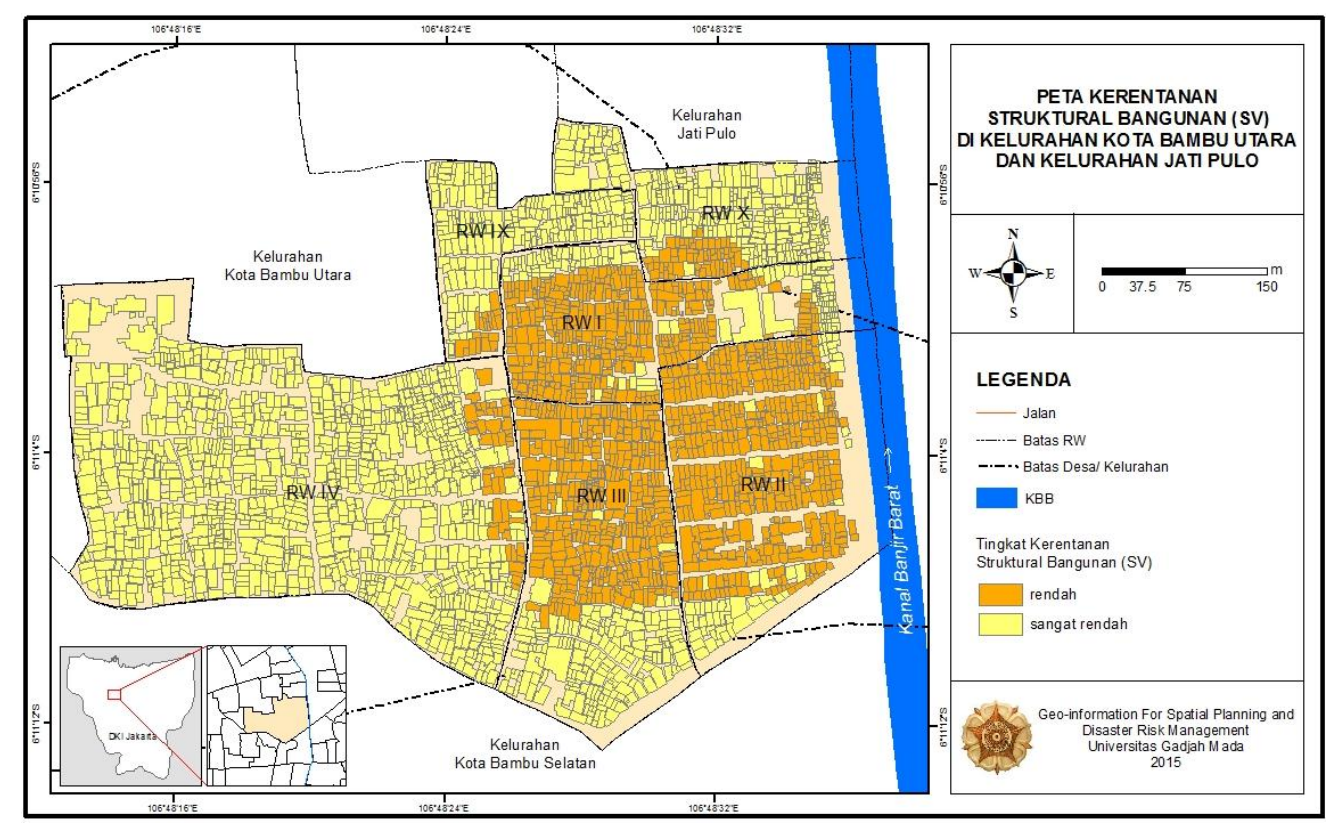

Gambar 11. Peta Kerentanan Struktural Bangunan (SV)

Tabel 3. Jumlah Bangunan Pada Tingkat Kerentanan Bangunan Karena Adanya Kontak Air (WV)

\begin{tabular}{clccccc}
\hline \multirow{2}{*}{ No. } & \multirow{2}{*}{ Kelurahan/ Lingkungan (RW) } & \multicolumn{3}{c}{ Kerentanan Bangunan Karena Adanya Kontak Air (WV) } \\
& & Sangat Rendah & Rendah & Sedang & Tinggi & Sangat Tinggi \\
\hline 1. & Kota Bambu Utara (I) & 130 & 1 & 83 & 0 & 354 \\
2. & Kota Bambu Utara (II) & 48 & 0 & 95 & 0 & 429 \\
3. & Kota Bambu Utara (III) & 180 & 3 & 79 & 0 & 335 \\
4. & Kota Bambu Utara (IV) & 1012 & 2 & 16 & 0 & 43 \\
5. & Kota Bambu Utara (IX) & 199 & 0 & 5 & 0 & 14 \\
6. & Jati Pulo (X) & 308 & 0 & 11 & 0 & 57 \\
\multicolumn{7}{r}{} \\
$\quad$ Jumlah & 1877 & 6 & 289 & 0 & 1232 \\
\hline
\end{tabular}




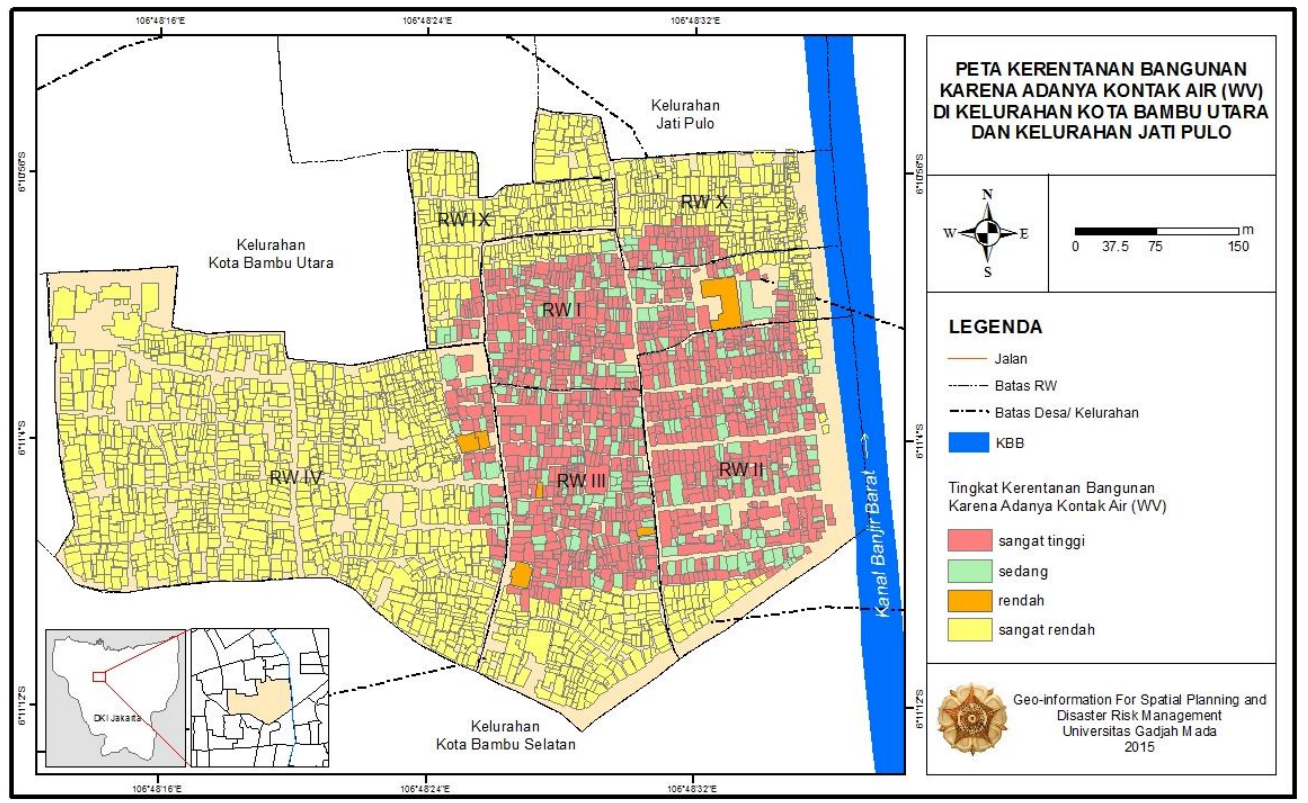

Gambar 12. Peta Kerentanan Bangunan Karena Adanya Kontak Air (WV)

Tabel 4. Jumlah Bangunan Pada Tingkat Indeks Kerentanan Relatif (RVI)

\begin{tabular}{ccccccc}
\hline \multirow{2}{*}{ No. } & \multirow{2}{*}{ Lingkungan (RW) } & Sangat Rendah & Indeks Kerentanan Relatif (RVI) & \\
& & Rendah & Sedang & Tinggi & Sangat Tinggi \\
\hline 1. & Kota Bambu Utara (I) & 141 & 75 & 352 & 0 & 0 \\
2. & Kota Bambu Utara (II) & 57 & 86 & 429 & 0 & 0 \\
3. & Kota Bambu Utara (III) & 185 & 77 & 335 & 0 & 0 \\
4. & Kota Bambu Utara (IV) & 1022 & 8 & 43 & 0 & 0 \\
5. & Kota Bambu Utara (IX) & 199 & 5 & 14 & 0 & 0 \\
6. & Jati Pulo (X) & 310 & 9 & 57 & 0 & 0 \\
& $\quad$ Jumlah & 1914 & 260 & 1230 & 0 & 0 \\
\hline
\end{tabular}

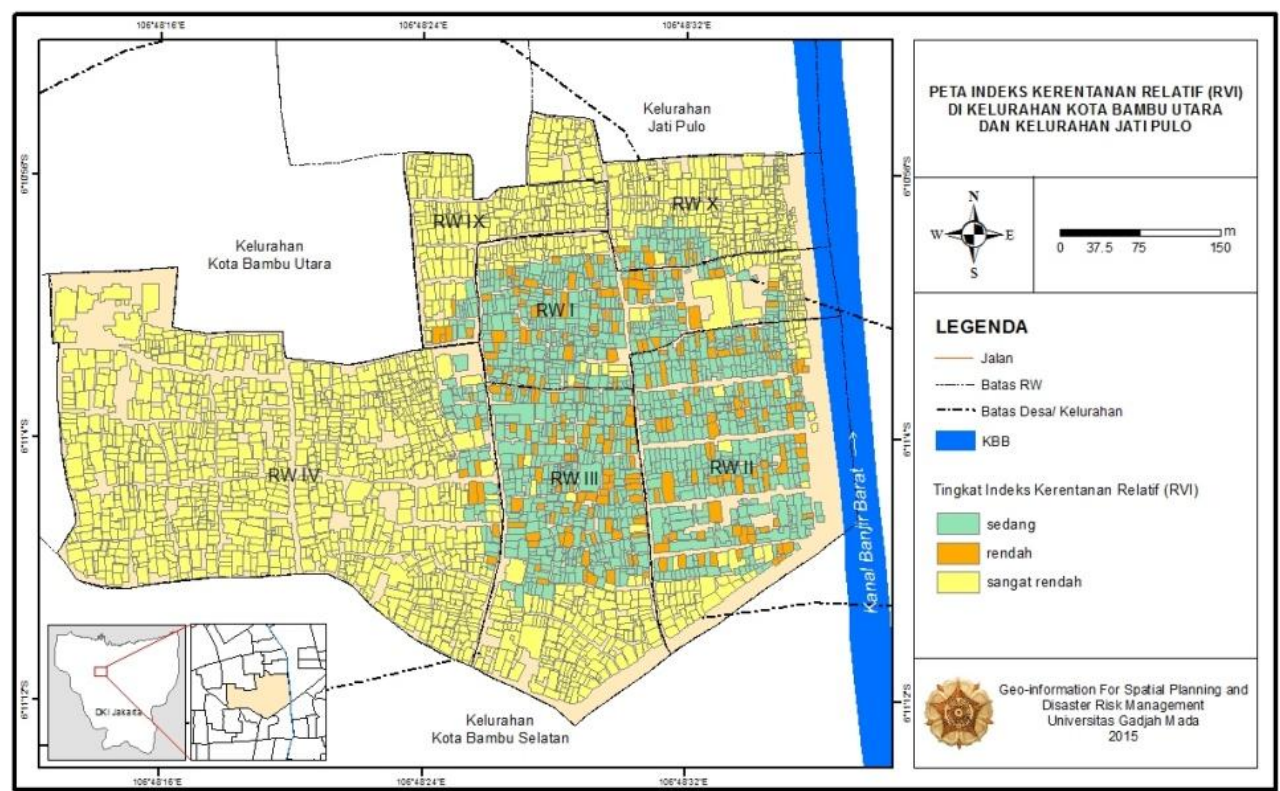

Gambar 13. Peta Indeks Kerentanan Relatif (RVI) 
Tabel 5. Harga Bangunan Berdasarkan Jenis Penggunaan Bangunan

\begin{tabular}{llcrrrr}
\hline & & & & \multicolumn{2}{c}{ Harga Bangunan (dalam Rupiah) } \\
No. & Penggunaan Bangunan & Jumlah & Minimum & Maksimum & Rata-rata & $\begin{array}{c}\text { Jumlah Harga } \\
\text { Bangunan }\end{array}$ \\
& & & & & & \\
\hline 1. & Rumah Sangat Baik & 32 & 71.505 .519 & 1.962 .940 .759 & 551.052 .511 & 17.633 .680 .361 \\
2. & Rumah Baik & 221 & 49.442 .513 & 1.413 .169 .052 & 235.106 .787 & 51.958 .599 .948 \\
3. & Rumah Sedang & 2867 & 2.250 .430 & 762.826 .685 & 81.203 .245 & 232.809 .703 .080 \\
4. & Rumah Buruk & 143 & 3.184 .503 & 133.521 .234 & 21.295 .359 & 3.045 .236 .407 \\
5. & Rumah Sangat Buruk & 50 & 1.791 .222 & 51.112 .473 & 14.370 .655 & 718.532 .751 \\
6. & Jasa dan Perdagangan & 75 & 22.795 .703 & 1.144 .409 .634 & 226.653 .772 & 16.999 .032 .866 \\
7. & Kantor Pemerintahan & 6 & 157.447 .391 & 1.422 .762 .559 & 625.651 .287 & 3.753 .907 .724 \\
8. & Sekolah & 2 & 1.541 .295 .440 & 3.216 .851 .081 & 2.379 .073 .260 & 4.758 .146 .521 \\
9. & Rumah Ibadah & 8 & 224.817 .570 & 537.342 .134 & 372.461 .555 & 2.979 .692 .441 \\
& & Jumlah Total Harga Bangunan & & & 334.656 .532 .100 \\
\hline
\end{tabular}

Dari hasil keseluruhan kerugian bangunan apabila dilihat dari batas administrasi; menunjukkan bahwa lingkungan RW II; Kota Bambu Utara mempunyai jumlah kerugian yang paling besar dari pada lingkungan lainnya yaitu sebesar Rp 18.443.045.840;-. Sedangkan untuk jumlah kerugian terkecil ada pada lingkungan RW IX; Kota Bambu Utara yaitu sebesar Rp 757.045.200;- (Tabel 6). Dari data tersebut dapat digunakan sebagai bahan pertimbangan mengambil keputusan bagi pemerintah daerah setempat untuk membuat program mitigasi bencana terhadap lingkungan RW dengan urutan prioritas kerugian terbesar.

Berdasarkan hasil perhitungan jumlah kerugian terhadap bangunan; maka peta kerugian bangunan selanjutnya dapat diklasifikasikan sesuai dengan kriteria seperti pada Tabel 7 dan Gambar 14.

Tabel 7. Klasifikasi Tingkat Kerugian Bangunan

\begin{tabular}{lc}
\hline \multicolumn{1}{c}{ Tingkat Risiko } & Kerugian Bangunan (Juta Rupiah) \\
\hline Sangat rendah & Risiko $=0-25$ \\
Rendah & Risiko $=25-50$ \\
Sedang & Risiko $=50-100$ \\
Tinggi & Risiko $=100-200$ \\
Sangat tinggi & Risiko $=>200$ \\
\hline
\end{tabular}

Berdasarkan definisi risiko yang sudah dijelaskan sebelumnya seperti pada Persamaan (3) yaitu penilaian risiko dengan memasukkan nilai probabilitas kejadian banjir. Nilai probabilitas kejadian banjir dihitung berdasarkan periode ulang banjir yaitu 25 tahun; sehingga diperoleh nilai probabilitas $(1 / \mathrm{T})$ sebesar $0 ; 04$. Untuk mendapatkan risiko spesifik bangunan maka mengacu dalam Persamaan (3) berarti mengalikan nilai probabilitas kejadian banjir dengan besarnya kerugian akibat banjir.

Jumlah risiko spesifikasi bangunan terbesar terdapat pada RW II Kelurahan Kota Bambu Utara yaitu sebesar Rp 737.721.855;- sedangkan risiko terkecil terdapat pada RW IX Kelurahan Kota Bambu Utara yaitu sebesar Rp 30.281.802;- (Tabel 8). Dengan berdasarkan kriteria tingkat risiko seperti pada Tabel 9; maka selanjutnya peta spesifik bangunan dapat disusun berdasarkan nilai probabilitas kejadian banjir dan besarnya kerugian (total loss) akibat banjir seperti terlihat pada Gambar 15.

Tabel 9. Klasifikasi Tingkat Risiko Spesifik Bangunan

\begin{tabular}{lr}
\hline Tingkat Risiko & Risiko Spesifik Bangunan (Juta Rupiah) \\
\hline Sangat Rendah & Risiko $=0-0,5$ \\
Rendah & Risiko $=0,5-1$ \\
Sedang & Risiko $=1-2$ \\
Tinggi & Risiko $=2-4$ \\
Sangat Tinggi & Risiko $=>4$ \\
\hline
\end{tabular}

\section{KESIMPULAN}

1. Pemodelan spasial bahaya banjir akibat kerusakan tanggul Kanal Banjir Barat yang terjadi di Jalan Latuharhary Tahun 2013 digunakan untuk mengetahui karakteristik model gagalnya tanggul; yaitu proses runtuhnya tanggul KBB diawali dengan mode rembesan (piping) pada struktur tanggul. Besarnya volume limpasan akibat banjir tanggul tersebut mencapai $744.700 \mathrm{~m}^{3}$ dengan luas area terdampak banjir sebesar 39;2 Ha. 
Tabel 6. Jumlah Kerugian Bangunan di Tingkat Kelurahan Kota Bambu Utara dan Kelurahan Jati Pulo

\begin{tabular}{|c|c|c|c|c|c|c|}
\hline \multirow[b]{2}{*}{ RW } & \multirow[b]{2}{*}{ Kelurahan } & \multirow[b]{2}{*}{ Jumlah } & \multicolumn{4}{|c|}{ Kerugian Bangunan (dalam Rupiah) } \\
\hline & & & Minimum & Maksimum & Rata-rata & $\begin{array}{c}\text { Jumlah Kerugian } \\
\text { Bangunan }\end{array}$ \\
\hline I & Kota Bambu Utara & 568 & 0 & 134.336 .000 & 21.936 .426 & 12.459 .889 .970 \\
\hline II & Kota Bambu Utara & 572 & 0 & 292.448 .000 & 32.243 .087 & 18.443 .045 .840 \\
\hline III & Kota Bambu Utara & 597 & 0 & 524.311 .000 & 24.909.274 & 14.870 .836 .500 \\
\hline IV & Kota Bambu Utara & 1073 & 0 & 184.804 .000 & 2.547 .492 & 2.733 .458 .380 \\
\hline IX & Kota Bambu Utara & 218 & 0 & 104.930 .000 & 3.472 .684 & 757.045 .200 \\
\hline $\mathrm{X}$ & Jati Pulo & 376 & 0 & 89.682 .400 & 4.753 .333 & 1.787 .253 .060 \\
\hline \multicolumn{6}{|c|}{ Jumlah Total Kerugian } & 51.051 .528 .950 \\
\hline
\end{tabular}

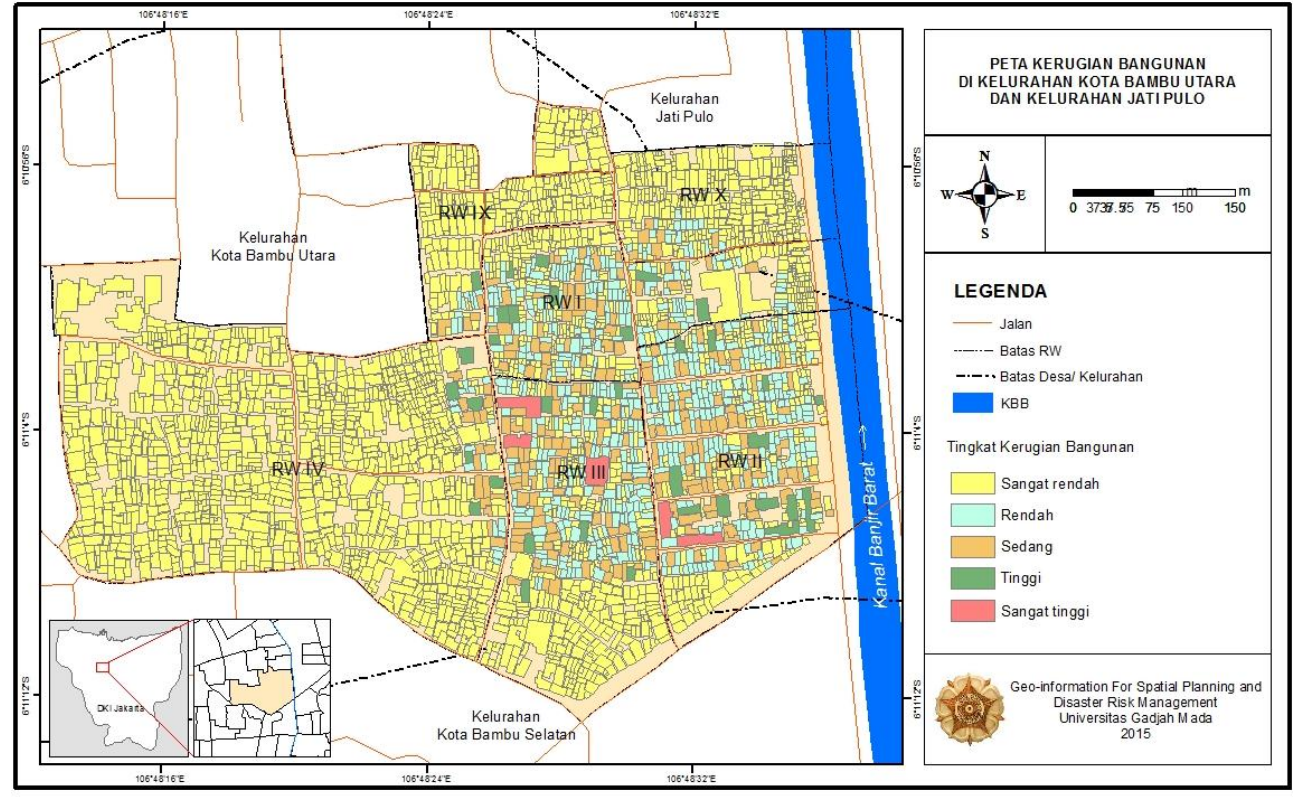

Gambar 14. Peta Kerugian Bangunan di Kelurahan Kota Bambu Utara dan Kelurahan Jati Pulo

Tabel 8. Risiko Spesifik Bangunan di Tingkat Kelurahan Kota Bambu Utara dan Kelurahan Jati Pulo

\begin{tabular}{|c|c|c|c|c|c|c|}
\hline \multirow[b]{2}{*}{ RW } & \multirow[b]{2}{*}{ Kelurahan } & \multirow[b]{2}{*}{ Jumlah } & \multicolumn{4}{|c|}{ Risiko Spesifik Bangunan (dalam Rupiah) } \\
\hline & & & Minimum & Maksimum & Rata-rata & $\begin{array}{c}\text { Jumlah Risiko } \\
\text { Bangunan }\end{array}$ \\
\hline $\mathrm{I}$ & Kota Bambu Utara & 568 & 0 & 5.373 .440 & 877.457 & 498.395 .610 \\
\hline II & Kota Bambu Utara & 572 & 0 & 11.697 .900 & 1.289 .723 & 737.721 .855 \\
\hline III & Kota Bambu Utara & 597 & 0 & 20.972 .400 & 996.370 & 594.833 .477 \\
\hline IV & Kota Bambu Utara & 1073 & 0 & 7.392 .160 & 101.899 & 109.338 .311 \\
\hline IX & Kota Bambu Utara & 218 & 0 & 4.197 .200 & 138.907 & 30.281 .802 \\
\hline $\mathrm{X}$ & Jati Pulo & 376 & 0 & 3.587 .300 & 190.133 & 71.490 .114 \\
\hline \multicolumn{6}{|c|}{ Jumlah Total Risiko Spesifik Bangunan } & 1.970 .571 .055 \\
\hline
\end{tabular}




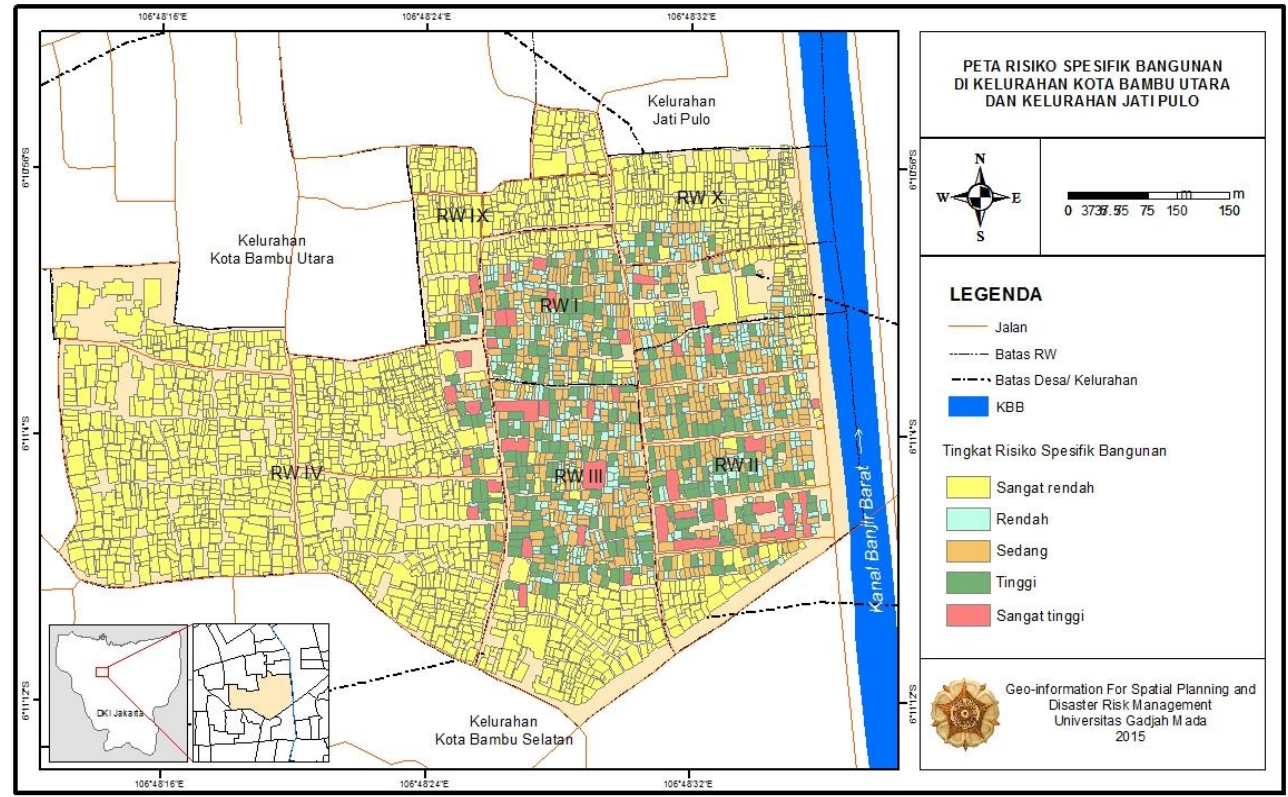

Gambar 15. Peta Risiko Spesifik Bangunan di Kelurahan Kota Bambu Utara dan Kelurahan Jati Pulo

2. Hasil dari identifikasi titik potensi rawan tanggul lainnya diperoleh titik rawan pada tampang lintang RS -156 (tanggul sebelah kiri) yang tepatnya berada di bawah jembatan layang Jati Baru. Simulasi runtuhnya tanggul pada lokasi tersebut dilakukan sebagai dasar untuk menentukan peta bahaya banjir yang mencakup sebagian wilayah kelurahan di Kecamatan Palmerah; Jakarta Barat. Hasil dari analisis menyebutkan besarnya volume limpasan yang keluar dari badan tanggul sebesar $160.750 \mathrm{~m}^{3}$ dengan luasan area terdampak banjir sebesar 9;5 Ha.

3. Penilaian kerentanan dan risiko difokuskan pada daerah terdampak banjir di dua kelurahan yaitu Kelurahan Kota Bambu Utara dan Kelurahan Jati Pulo. Hasil penilaian kerentanan bangunan secara kuantitatif menyebutkan bahwa pada lingkungan RW II Kelurahan Kota Bambu Utara merupakan daerah yang memiliki tingkat kerentanan rendah dan sedang. Pada penilaian kerugian bangunan menyebutkan tingkat kerugian terbesar juga ada pada bangunan di lingkungan RW II Kelurahan Kota Bambu Utara; yaitu jumlah kerugian bangunan mencapai Rp 18;44 Miliar dari total kerugian bangunan keseluruhan sebesar Rp 51;05 Miliar. Sedangkan hasil yang sama diperoleh pada penilaian risiko spesifik bangunan yaitu pada lingkungan RW II Kelurahan Kota Bambu Utara diperoleh tingkat risiko terbesar yaitu $\mathrm{Rp}$ 737.721.855;- dari total risiko spesifik bangunan sebesar Rp 1.970.571.055;-

\section{DAFTAR PUSTAKA}

Badilla, C. E. (2002) Flood Hazard. Vulnerability and Risk Assessment in The City of Turrialba. Costa Rica. Thesis. ITC. Enschede.

Dall'Osso, F., Gonella, M., Gabbianelli, G., Withycombe, G., dan Dominey-Howes, D. (2009). A Revised (PTVA) Model for Assessing the Vulnerability of Buildings to Tsunami Damage. Natural Hazards Earth System Science. (9), $1557-$ 1565.

Gunawan, R. (2010). Gagalnya Sistem Kanal Pengendalian Banjir Jakarta dari Masa ke Masa. Jakarta. Kompas.

Hastings, S.M. (2005). Extraction of Flood Risk-Related Base-Data from Multi-Source Remote Sensing imagery. Thesis. ITC. Enschede.

Istiarto. (2012). Simulasi Aliran 1-Dimensi Dengan Bantuan Paket Program Hidrodinamika HEC-RAS. Yogyakarta. UGM.

Kusnadi, I. (2013). Kajian Risiko Bencana Banjir Pada Kawasan Pertemuan Sungai Keyang. Slahung dan Sungkur di Ponorogo. Tesis. Universitas Gadjah Mada.

Maiti, S. (2007). Defining a Flood Risk Assessment Procedure using Community Based Approach with Integration of Remote Sensing and GIS. Thesis. ITC. Enschede.

Sakethi. (2010). Mengapa Jakarta Banjir. Jakarta. PT Mirah Sakethi.

Untung W. 2013. Kerugian Banjir Jakarta Bisa Tembus Rp 15 Triliun. Diakses pada 7 November 2013 dari http://www.tempo.co/read/news/2013/01/18/21445 
5359/Kerugian-Banjir-Jakarta-Bisa-Tembus-Rp-15Triliun.

Van Westen, C. (2009a). Multi Hazard Risk Assessment. Educational Guide Book Session 1: Introduction to Disaster Risk Management. diedit oleh Cees van Westen. ITC. Enschede. The Netherlands.
Van Westen, C. (2009b). Multi Hazard Risk Assessment. Educational Guide Book Session 6: Risk Analysis. diedit oleh Cees van Westen. ITC. Enschede. The Netherlands.

Zainuddin, H. M. (2013). Banjir Jakarta. Jakarta. PT. Zaytuna Ufuk Abadi. 